\title{
Framework for local government to implement integrated water resource management linked to water service delivery
}

\author{
EH Haigh, HE Fox and HD Davies-Coleman* \\ Institute for Water Research, Rhodes University, PO Box 94, Grahamstown 6140, South Africa
}

\begin{abstract}
The Water Services Act (No. 8 of 1997) of South Africa states that water service delivery is the responsibility of local government as Water Services Authorities. The principal legal responsibility is to complete a Water Services Development Plan (WSDP) every 5 years with annual review. The WSDP encapsulates all the responsibilities and tasks required in water service delivery. However, it does not spell out local government's role in water resource protection or its responsibilities as far as integrated water resource management is concerned. It is well known in South Africa that there is a challenging level of inadequate capacity in technical and administrative skills in local government to adequately fulfil water service delivery. This paper highlights the consequences of this incapacity for municipalities and their difficulties in fulfilling their responsibilities as service providers. A framework is provided within which improvements can be brought about, with guidance on how to engage in the practice of integrated water resource management (IWRM) in the context of the legal framework for water services. The additional tasks and changes required to practise IWRM are set in the context of the WSDP. The framework provides a guide for a municipality to first accomplish an adequate WSDP, and then to gradually implement IWRM. A discussion on the skills needed to accomplish, firstly, a comprehensive WSDP, and secondly, IWRM, is included.
\end{abstract}

Keywords: local government mandates, water service delivery, water service planning, integrated water resource management, skills and training needs, water resource management, solid waste management

\section{Introduction}

Internationally, in recent years, a more integrated approach to the management of natural resources has been advocated. Integrated water resource management (IWRM) is such a process and it promotes the co-ordinated development and management of water and land so as to maximise economic and social welfare without compromising the sustainability of vital ecosystems (Global Water Partnership, 2000; DWAF, 2004a). One of the aims of IWRM is to improve all aspects of water resource management progressively - the way we collect water, store water, distribute water, conserve water and keep water pure. IWRM thus aims to find a balance between the social, environmental and technological perspectives of water resource management.

The South African National Water Act (Act 36 of 1998) (NWA) promotes an integrated catchment-based approach to water resource management. The law promotes a more equitable and sustainable use of our water and makes water 'everybody's business'. Since we all have a right to water, we also have a right to participate in the way it is managed and allocated - with participation being organised in terms of catchments (NWA, Chapters 2 and 7). Local government (LG), being strategically located between the national policy-making level and water consumers, has a significant role to play in water management and in engaging local communities to participate in IWRM processes.

According to the South African Constitution (Act No. 107 of 1996) and the Water Services Act (Act No. 108 of

\footnotetext{
* To whom all correspondence should be addressed.

용 +27(46) 603 8055; fax: +27(46) 6038822 ; e-mail: h.davies-coleman@ru.ac.za

Received 11 June 2009; accepted in revised form 31 May 2010
}

1997) water service delivery is a core responsibility for local government, whether as a water services authority or as a water services provider. Carrying out this responsibility faultlessly and lawfully should be the goal. IWRM would require a general review of management practices. From our observations, municipal officials tend to function within their directorates without sufficient cross-directorate interaction. Municipal officials are traditionally pre-occupied with delivering water and sanitation to households and generally do not want to consider the health of rivers and wetlands as part of their sphere of responsibility. In order to practice IWRM, they will have to adopt a holistic and integrated approach to water service delivery and water resource management.

\section{The IWRM plan guidelines for local authorities}

In 2007 a report entitled Integrated Water Resource Management Plan Guidelines for Local Authorities was published under the auspices of the Water Research Commission (WRC) (Burke, 2007). This guideline sets out a new integrated approach to the management of water resources and water services for local government. If the guideline is to be implemented, municipal management structures will have to be extensively reviewed. This task and a new approach to management would be a daunting prospect to a constituency already failing to comply adequately with the Water Services Act mandates, under present management systems and with current available capacity.

This paper examines how local government can engage in the practice of IWRM in the context of the legal framework for water services. The framework presented here provides a more consolidated guide for local government officials on how to improve water service delivery with water resource management, in line with the tasks mandated in the WSDP, without 
undertaking immediate restructuring. This paper aligns the WSDP and the IWRM Plan Guidelines (Burke, 2007), identifying tasks common to both, thus offering municipal officials a way to incorporate IWRM tasks into water service delivery. The paper then highlights those additional tasks that are required when practising an integrated system of water resource management.

To achieve an excellent level of water service delivery a step-by-step approach for improvement is needed. Suggestions are offered on how to achieve such a phased approach. The approach takes into account the responsibilities that municipal officials already have as well as advocating greater overall integration of management systems.

At the municipal level, the impact of human activity on the environment is especially noticeable, particularly in planning development. For this reason, improved environmental management and water should be placed at the heart of all development decisions (DWAF, 2005). Municipal officials involved in environmental management should be encouraged to take a more broad-based approach than the narrow 'public health' focus that officials tend to adopt. Among the issues that need to be considered are the environmental impact of land management such as zoning for recreational spaces and water use; stormwater management; waste disposal; the preservation of wetlands and green open spaces as soak-aways; the monitoring of the downstream effects of effluent, in particular greywater; and finally the equitable distribution of water resources through catchment management.

\section{Research area}

Makana Municipality was chosen as the pilot study because it represented a Category B Municipality, with Rhodes University, Grahamstown, conveniently located in its midst. Makana is one of 9 municipalities in the Cacadu District Municipality in the Great Fish River Catchment, of Water Management Area 15: Fish to Tsitsikamma. The Municipality includes 3 urban settlements and 8 rural villages/centres.

\section{Research methods}

The overall research approach comprised the following:

- Municipal mandates relating to environmental management and service delivery, particularly where related to water, were tracked through all the relevant acts (National Water Act, Water Services Act, Municipal Systems Act, and National Environmental Management Act).

- The need for water resource protection in relation to waterrelated services (e.g. the provision of water supply and sanitation; and stormwater management) and IWRM provisos was examined and linked.

- The considerable challenges to LG to undertake responsible WSD, particularly where capacity and financial resources are limited, were examined in the context of IWRM. The lack of municipal and water management area boundaries coinciding was noted as an added challenge.

- Using Makana Local Municipality as a case study, present levels of compliance to existing legislated norms and standards were compared, through interviews with relevant stakeholders and by examining the Makana WSDP. A number of recommended actions were drafted according to these findings and were published in 2008 in a WRC research report (Haigh et al., 2008).

\section{Results}

\section{Overview of the legal framework for LG}

The powers and functions of the spheres of government are enshrined in the Constitution. In pursuit of the constitutional mandate of a developmental local government, the White Paper on Local Government was formulated in 1998, with the subsequent promulgation of a suite of local government legislation within a financial framework afforded by the annual Division of Revenue Act.

The division of such powers and functions is developed upon in the Municipal Structures Act (Act No. 117 of 1998), the Municipal Systems Act (Act No. 32 of 2000) and the subsequent Amendment Act (Act No. 33 of 2000), particularly in respect of local government spheres (local and district municipalities). This suite of legislation further includes the Intergovernmental Relations Framework Act (Act No. 13 of 2005) the Municipal Demarcation Act (Act No. 27 of 1998), Local Government Finance Management Act (Act No. 56 of 2003), Local Government Property Rates Act (Act No. 6 of 2004) and the Disaster Management Act (Act No. 57 of 2002).

The Development Facilitation Act (Act No. 67 of 1995) states that an integrated development plan (IDP) must be prepared to ensure proper co-ordination and integration of development. IDPs are the most important mechanism available to government to transform structural differences in South Africa's previously divided society. The IDP process is also one of the primary means of developing a community through the promotion of public participation in its analyses and planning phases (Geyer, 2006). This process, a legal requirement of LG, prepares officials and politicians for the requirement of integrated planning and management (Act No. 32 of 2000; Act No. 36 of 1998). However, as the IDP is presently set out in the Municipal Systems Act (No. 32 of 2000), it is not required that water availability and demand be considered during all parts of development planning, and neither does the IDP process demand a discussion of how development will impact natural resources. In addition, the IDP deals separately with those services that impact water resources such as solid waste management, stormwater management, and water service and sanitation. This is not conducive to IWRM.

Given the cross-sectoral nature of water, all legislation has at least some application to water resources and service management. The National Environmental Management Act (No. 107 of 1998) and the National Water Act direct the components of the municipal IDP, reviewed annually. The Integrated Waste Management Plan and the WSDP are subsets of the IDP. At present there is no statute that prescribes the duties of LG in terms of IWRM.

As Water Services Authorities, municipalities are ultimately accountable for the delivery of water service and sanitation to consumers, whether or not they fulfil the provider function. Four tasks are identified for the Water Services Authority (WSA). They need to:

- Adapt internal arrangements and put governance mechanisms in place to effectively regulate water service by developing and implementing policies such as by-laws and regulating competence.

- Take on the cost-effective and sustainable management and operation of water service infrastructure through determining tariffs, managing equitable share allocation, service level planning, capital infrastructure investment prioritisation and implementation. 
- Make appropriate arrangements for the sustainable, efficient and effective provision of water services across their areas of jurisdiction through a Water Services Provider under contract or by themselves (Municipal Systems Act No. 32 of 2000, Section 78). The provider function relates to practical implementation including day-to-day operations. Apart from providing safe potable water, water services include providing sanitation, treating wastewater and effluent, effecting repairs together with preventative and major maintenance as well as revenue collection and related financial management. In addition, provider functions extend to customer relations and communication, including information on the service being delivered as well as health and hygiene awareness. Related and linked services that are the responsibility of LG include managing solid wastewater and stormwater in ways that ensure a healthy environment.

- Draft and adopt a WSDP every 5 years, with annual review, as part of its IDP. This is the principal legal responsibility of LG under Act 108 of 1997 (Sections 12-15). The WSDP encapsulates all the responsibilities and tasks required of LG in water service delivery and forces a WSA to consider each aspect.

\section{Compliance}

Many municipalities, however, fail to comply with the prescripts of the WSDP mainly because of ignorance and lack of capacity both in experienced staff and data systems. They fail to manage their infrastructure adequately, have poorly run and inadequate sewage treatment plants and overlook adequate stormwater management in semi-formal and high-density suburbs (Schreiner, 2007). All of these ultimately result in river pollution. Few municipalities ensure that the rivers are kept clear of alien vegetation. Most municipalities fall short of maintaining an environment that supports the health of citizens, especially when it comes to the discharge of effluent from waste-water treatment plants, and most do not monitor the health of their water resources (Schreiner, 2007).

\section{The Strategic Framework for Water Services}

The Strategic Framework for Water Services (DWAF, 2003) addresses the full spectrum of water supply and sanitation issues, thus serving as an umbrella framework for the entire water service sector. It gives a set of overall IWRM goals and outlines an institutional framework as well as operational frameworks (financial, planning and implementation) that need to be set or be in place to achieve these goals. This Strategic Framework encompasses a number of tiered planning strategies that are inter-linked so as to inform one another; and incorporates a national implementation strategy which covers both the management and allocation of water. Essentially the implementation strategy is described in 2 pieces of legislation: the National Water Resource Strategy (DWAF, 2004a) and the Catchment Management Strategy (DWAF, 2007a). In its management of local water resources, LG must ensure compliance with both.

Officials working in the areas of water service delivery need to ensure that the WSDP and the IWRM Plan are in alignment with the Catchment Management Strategy. In water management areas where a Catchment Management Strategy has not yet been developed, the WSDP and IWRM plan should be aligned with the National Water Resource Strategy. These plans should inform the development of the Catchment Management
Strategy (DWAF, 2007a). In terms of the Constitution, additional roles may be allocated to local authorities if resources are available.

All the strategies and planning tools are aligned to and supported by business plans that must be reviewed annually by the LG. In turn, the business plans should be aligned to and be mutually informative of the provincial IDPs for both municipal and regional entities.

\section{The Water Services Development Plan, management tools and plans}

The WSDP (DWAF, 2001) deals with planning for water service provision, water demand management and wastewater treatment. To develop a strong plan, up-to date information from the municipality's records is required. Billing systems and associated records become critical. If the municipality does not have the capacity to draft a WSDP, then the local municipality is responsible for providing information to the designated consultant drafting the plan and to the District Municipality and the Catchment Management Agency. The WSDP is essential for the completion of the province's IDP and must be aligned with this. Drafting a WSDP reveals the gaps and problems experienced in water service delivery, although it does not reflect information on solid waste management or planning procedures.

The WSDP consists of 10 business elements (see Table 1). To understand each business element, resources, systems, service, laws, and infrastructure already in place must be identified. Each business element requires a description (called a 'profile') including the following, listed here for referral:

- SOCIO-ECONOMIC PROFILE: The social aspects of the population served by the municipality. This includes municipal demographics with income and employment patterns and the status of health service, sanitation and waterborne diseases.

- SERVICE LEVEL PROFILE: An overview of water and sanitation services in place as well as any plans for improvement. The following are required: an assessment of the quality and level of service reaching the people in the municipality, including management of all wastewaters; and the service and management for waste removal including dry waste from industry. Industries producing toxic effluent ('wet industries' such as tanneries) need special attention.

- WATER RESOURCE PROFILE: The quality and quantity of water available to the municipality (both surface and groundwater).

- WATER CONSERVATION AND DEMAND MANAGEMENT (WC/DM): Quantities required, with programmes required to set targets for the use and conservation of water. Conservation includes education of consumers, keeping track of leaks, metering water use, and control of alien vegetation.

- WATER SERVICE INFRASTRUCTURE: Assessment, maintenance and management of water and sanitation infrastructure including water storage structures such as reservoirs and dams, an evaluation of the water service assets, and such related elements as staff expertise.

- WATER BALANCE: The quantities of bulk water, including volumes treated for consumers, and volumes entering and being released as effluent from water treatment works.

- INSTITUTIONAL ARRANGEMENTS: The laws and 
regulations that govern the management and allocation of water must be understood.

- CONSUMER SERVICE PROFILE: People are receiving the service to which they are entitled. People education, protective by-laws, and opportunities for consumer complaints are required.

- FINANCIAL PROFILE: The financing of the different water-related services.

- LIST OF PROJECTS: Lists of projects currently underway or planned in the future, and the means by which their development can be tracked.
In Table 1 each of the business elements outlined above is colour coded according to the WSDP. For each business element, local authorities complete the following 4 processes:

- A situation assessment: infrastructure, available water, income and management are critical. The associated data collection system requires a person able to analyse the information.

- Future trends and goal: particularly trends in terms of population growth and economic development. These should be aligned with the IDP.

- Strategic gap analyses: water service needs.

- Implementation plans: how the needs will be addressed with priorities listed.

\section{TABLE 1 \\ Links between the tasks as set out in the WSDP and the Integrated Water Resource Management Plan (IWRMP) as suggested by Burke (2007)}

The numbering systems of the 2 original documents - i.e. the WSDP and IWRMP, have both been retained, leaving the numbering sequence in Table 1 unconventional but allowing cross-reference to the original documents.

The business elements and tasks of the WSDP v.12 are in the left column and the related tasks of Burke's IWRMP on the right. While the wording in the IWRMP is at times slightly different, the content and message are the same. All new tasks to fulfil IWRM criteria are highlighted in red. Red borders around cells indicate tasks that need more information, or that have been added to the existing business areas of the WSDP. Tasks referring to the Integrated Waste Management Plans are coded brown (DWAF, 2004b).

\section{WSDP business elements and tasks}

SECTION E. IDP and WSDP Goals and Integration

E1. IDP priority issues related to water service

E3. IWRM sub-goals

Water resource protection \& WC/DM

SECTION D. Background to the area

D1. Location, maps, etc.

D2. Maps and descriptions of water services authority, settlements, infrastructure for public and economic activities

D3. Physical perspective: topography, climate, natural environmental status

\section{F1. Socio-economic profile (Demographics, employment and} income)

Current consumer profile, including wet and dry industrial consumer units and commercial units

Present and projected population

Demographic trends, age and gender profiles

Employment profile and household income

Economic profiles and trends

Health-service profile

Water-borne diseases and sanitation access

F2. Service level profile

(targets set must align with IDP)

Residential consumer units for water and sanitation according to

service levels

Sanitation systems

Greywater management

Pit emptying and sludge disposal

Public institutions, dry industries

Wet industries' water needs, effluent permits and sanitation needs

Raw water consumers

\section{IWRMP tasks}

8.1 Introduction to local authority IWRM objectives

8.2 Local authority details

8.3.2. Locality plan - organogram \& contact details person/ champion/ coordinator for IWRM

8.3.1 Baseline information - topography, climate, GIS maps and demographics.

8.5.2. Dry weather and peak flows (WR90 or WR2005) location of flood lines for 1:50 and 1:100 year storm events (WR2005 = water resource fact books and maps from DWA)

8.5.2. Hydrology: flow data, mean annual runoff (WR90)

8.5.1. Description of catchment(s), water management area and resource class; overview of geology of area

8.3.4. Regional (CMA) perspective

8.2. \& 8.3.3 Demographics

8.10. Work creation and poverty alleviation

8.9.3. Risks to human health

\subsection{Water use and management}

8.7.2 Surface water users (sectors, etc.)

8.6.4 Groundwater users

8.7.4 Sewage

8.7.6 Greywater (urban runoff from under-serviced/unserviced area)

8.10.7 Pollution control

8.8.2 Industrial, any other waste (sanitation)

8.8.1 Waste management

8.7.10 Recreational water uses

8.7.5 Stormwater management 


\section{F3. Water resources profile}

Water source situation assessment surface and groundwater volumes used and projected for 5 years

Water quality profiles - raw and treated urban and rural and effluent discharged (water use as specified in NWA S.21f,g,h)

Linked to Integrated Waste Management Plan (IWRM)

Pollution contingency measures

Sanitation systems

\section{F4. WC/DM (also touches public participation (PP) and education)}

Situation assessment detailing targets and management programmes and resources for reduction of pressure and water loss as well as consumer education

Record of leaks and illegal connections

Leak and meter repair programmes

'Working for water' and artificial aquifer recharge

F5. Water services infrastructure

Situation assessment of existing infrastructure for both water (bulk and reticulation) and sanitation; including history, ownership, type,

values, capacity and operational status (functionality) for both surface and groundwater

Operational and separate maintenance plans for each component

Asset management assessment and programmes and capacity for each element

Dam safety measures, risk assessment and management policies, emergency procedures

Staffing levels, educational status, capacity building and training, budgeting, availability of manuals

F6. Water balance (operational)

Bulk water utilised annually, treated water supplied to consumers by type

Volume received at treatment works and effluent released to water resources

F7. Water service institutional arrangements (also section on administration)

WSA and WSP policies, by-laws, WC/DM plans

Indigent policy, tariff structures, procurement policy, credit and debt collection policy; performance management system

Representation on CMA or Water Board

Includes operational strategies, stakeholder participation
8.5 \& 8.7.2 Surface water situation assessment

8.5 Surface water situation assessment 8.6. Groundwater situation assessment

8.5.6-9. Surface water monitoring programme - quality 8.5.10. Overview of surface water quality, quantity and river health 8.6.5 Groundwater quality, monitoring programme (quality and quantity) and location of stations

8.6.7 Overview of groundwater quantity and quality

8.7.5 Stormwater

8.10 Pollution control

8.10.7. Surface water quality

Chemical and biomonitoring programmes

Monitoring systems report

8.10.3 Water conservation /water demand management

8.12.2 Operation and management systems.

8.12.4 Education and awareness

8.7.2 Water supply

8.7.3 Reservoirs, wastewater treatment and stormwater plans

8.7.4 Sewage

8.7.1 Legal framework - summary of NWA Section 21 water uses regulations within Local Authority and Regulation 704 (mining) or any other applicable regulations

8.1.2.2 Operation and management

This falls under many different categories in WSDP

Database of abstraction and monitoring boreholes; aquifer parameter and aquifer test data

8.7.5 Stormwater

8.10.10 Emergencies and contingencies

8.12.3 Records of staff training

8.7.11 Water balance (8.7.2)

\section{F8.Consumer service profile}

Complaints and breaks register and follow-up record for urban and rural water, and sanitation problems.

Assurance of supply, supply interruptions and what type of water quality for urban and rural.

Education and awareness and public participation for water supply and sanitation

Billing systems and access to pay points

Are by-laws in place?
8.10 Management Systems and Strategies to Implement IWRM 8.12 Operational Management

8.9.6 Performance monitoring (legally required by IDP) 8.10.3 WC/DM

8.12.2 Operation and management procedures, including staff training 8.12.5 Partnerships with residents, NGOs and business

8.10.2 Catchment management

8.10.4 \& 6 Environmental management i.e. land, river and wetland management strategies

8.10.7 Pollution control strategy

8.12.1 Project planning, implementation \& management

8.9.4 Key performance areas (KPAs), key performance indicators (KPIs) and monitoring plan

8.12.7 Records of correspondence with other regulatory authorities

8.12.9 Auditing and reporting (internal and external auditing)

8.12.4 \& 6 Communication, including education and awareness (service and pollution control)

8. Recording and reporting of incidents

8.10.9. Emergencies and contingencies

8.10.9 Emergencies and contingencies

8.11.4 Work creation and poverty alleviation

8.10.9 Community/stakeholder participation strategies

8. Records of partnerships with residents, NGOs, business, etc. 


\begin{tabular}{|c|c|}
\hline F9. Financial profile & $\begin{array}{l}\text { No separate category for finances, budget provision and alternative } \\
\text { funding sources }\end{array}$ \\
\hline $\begin{array}{l}\text { Capital expenditure on new connections for water and sanitation and } \\
\text { sources of income i.e. MIG }\end{array}$ & \multirow[t]{4}{*}{ Budget provision and alternative funding sources } \\
\hline Operating costs for water and sanitation & \\
\hline Operating income from tariffs and equitable share & \\
\hline Tariff structures for all types of consumers. & \\
\hline F10. List of projects & 8.11 Prioritisation of projects. \\
\hline Annual water and sanitation project list & 8.11.1 Methodology and selection criteria. \\
\hline \multirow[t]{2}{*}{ Sustainability projects } & $\begin{array}{l}\text { 8.11.2 Rehabilitation and mitigatory measures: management options to } \\
\text { mitigate impacts and risks } \\
8.11 .4 \text { \& } 5 \text { Work creation, poverty alleviation - identified projects list }\end{array}$ \\
\hline & \begin{tabular}{|l} 
8.11.6 Timeframes for implementation \\
8.12.1 Project planning, implementation and management
\end{tabular} \\
\hline 12. IWMP & $\begin{array}{l}\text { 8.8.1 \& } 2 \text { Waste management } \\
\text { 8.8.3 \& } 4 \text { Hazardous waste }\end{array}$ \\
\hline 12. IWMP & $\begin{array}{l}\text { 8.3 Identification of boreholes of concern (quantity and quality) and } \\
\text { potential pollution sources }\end{array}$ \\
\hline 12. IWMP & 8.2 Domestic, industrial, any other wastewater \\
\hline Bridges, stormwater infrastructure (NWA Section $21 \mathrm{c}, \mathrm{i}$ ) & 8.7.7 Diversions, alterations and river crossings \\
\hline \multirow[t]{2}{*}{ Same category as greywater } & 8.7.8 Potential emergency/contingency discharges \\
\hline & $\begin{array}{l}\text { 8.9.1 Risk assessment including impacts and risks to aquatic environ- } \\
\text { ment, and cumulative risk assessment }\end{array}$ \\
\hline $\begin{array}{l}\text { Alignment with provincial and national government } \\
\text { Attendance at relevant forums }\end{array}$ & 8.10.8 Co-operative governance strategy \\
\hline Linked to IDP and zoning regulations & $\begin{array}{l}\text { 8.10.6 Land use } \\
\text { 8.10.5 Groundwater protection and recharge }\end{array}$ \\
\hline F3.2.1.6 & $\begin{array}{l}\text { 8.10 Identification of areas of concern and potential pollution sources - } \\
\text { not for Category B 8.5.8 Air quality monitoring programme }\end{array}$ \\
\hline
\end{tabular}

\section{Implementing IWRM through the WSDP}

After a WSDP has been completed and implemented, the development and implementation of an IWRM plan is possible. Table 1 links the water service delivery (WSD) tasks to the IWRM Plan developed by Burke (2007). Burke's IWRM Plan is an excellent information and resource document and should be used as the technical supporting document when application for water use authorisation is made.

At present the completion of the WSDP is generally outsourced to consultants. The authors believe that it should be an in-house planning process. This is potentially a bottleneck to the implementation of IWRM, but not impossible if undertaken in phases. The 'Self Appraisal Needs Analysis for Municipal Water and Sanitation Service Delivery' (DWAF, 2007b) is a useful tool in this regard.

We suggest the following phases:

- PHASE 1 - SITUATION ASSESSMENT: Get the basics right. Set systems in place to do a comprehensive situation assessment. Collect data and generate information from the dataset.

- PHASE 2 - WATER QUALITY MANAGEMENT:

Discharge permits must be made public and acknowledged by officials; water use by-laws to be promulgated; and a monitoring system to track compliance with permits and by-laws to be in place. Liaison with the Ministry and or Catchment Management Agency is essential.

- PHASE 3 - DEVELOP OPERATION, MAINTENANCE AND REHABILITATION STRATEGIES: Improve the short and long-term management plans and systems for the mandated responsibilities to ensure sustainability.

- PHASE 4 - MONITORING AND REVIEW OF SERVICE: Assess service quality, identify areas of concern and plan for improvement.

- PHASE 5 - IMPLEMENTATION STRATEGIES FOR IWRM: Move from current approaches in municipal management to more integrated and effective management.

\section{Outline of phased approach}

\section{PHASE 1 - SITUATION ASSESSMENT}

\section{STEP 1: Collection of data and development of a functional and analysable database (spreadsheet)}

Purpose: Improvement of the levels and storage of information available for completing the WSDP and enabling the completion of the WSDP (see WSDP Section F2.1.1, 2.2, 2.3, 2.5, Section F3.1.1.1 and 2, and Section F9, Table 1).

Note: All municipalities have a basic register for billing but many cannot be analysed. If the database is electronic but not analysable, a system must be devised where information that is already collected can be downloaded and stored in Microsoft Excel and Access before the end of each month when the bills are prepared. To be truly useful each erf and water meter number should have geographic coordinates assigned in the database for possible incorporation into a GIS system. A GPS will have to be purchased to accomplish this and meter readers trained to use it.

Task: Decide on information to be collected and structure of database. Information must include:

\section{Consumer profile:}

- Location of residential metered households, their demand and the generated revenue. Metered public institutions, 
hospitals, businesses and industries (with wet or dry classification attached). A start can be made on recording information about household meters.

- Type of sanitation and status of each category of consumer

- Presence/absence of on-site rainwater tanks and stormwater disposal method of each district; and note illegal stormwater routing

Water resources profile:

- Origin, volume and quality of raw water available from each source.

- Volume of discharged used water and estimate of stormwater discharge.

- Capacity of downstream receiving streams.

\section{Financial profile:}

- Develop a financial profile for water and sanitation service consisting of total monthly income from water sales and expenditure on chemicals, plant operations (electricity, staff) and maintenances. This information is needed to generate budgets for the service and ensure a savings structure for large maintenance projects. Ideally, this service should then be ring-fenced to ensure adequate finances available for operations and management (National Treasury, 2006).

Task: Develop and implement a staff recruitment campaign.

\section{STEP 2: Information generation}

Purpose: Generation of information that will form the basis for the WSDP and enable the calculation and drafting of a water balance profile (WSDP Section 6. Development plans, for example housing) and thus service delivery goals will therefore be more realistic and feasible.

Tasks:

- Provide a summary of monthly demand for bulk-water and of realised income from volume of purified water supplied that can be computed to annual demand and monthly and annual deficits or surpluses.

- Compute total monthly output into wastewater treatment plant to annual discharge. Inability to provide this information indicates inadequate metering infrastructure, which should be addressed (planned and budgeted for) to improve data collection.

- Develop a financial profile. The ability to cost water service delivery on a monthly basis and then to calculate an annual financial profile of water service delivery will gradually develop as each area is progressively brought into the system. Running parallel systems may be necessary for a year or two and careful planning is required.

\section{STEP 3: Lay the groundwork for operational plans}

Purpose: Enable the completion of WSDP Sections F5, F7 and F8. This work may be accomplished in tandem with Step 2.

Tasks: Water infrastructure and service profile

- Comprehensive description (type, size, age \& status) and geographical location of all infrastructure for surface water, groundwater and sanitation including a present state assessment including all bulk meters. Gradually improve the recorded information on the household metering system and include in the system. This will result in a comprehensive database of all infrastructure.

- Record current management strategies for customer service, complaints registration and response, as well as infrastructure maintenance and rehabilitation. This will enable the identification of gaps in management protocols.

- Organogram and staffing levels. Status of staff complement (posts and appropriate competency) of the WSA and the WSP for both water and sanitation service.

- Draft a recruitment and skills development plan for the water services sector.

\section{OUTCOMES OF PHASE 1}

Calculation of the following is now possible:

- Water balance - and therefore an assessment of unaccounted for water. This is the first step towards developing Water Conservation and Demand Management plans (DWAF, 2007c).

- Financial plan detailing income and expenditure and the derivation of unit costs of service.

Once Phase 1 is in place and carried out successfully for 1 year, the completion of the major business elements in the WSDP may begin; an initial self-assessment and gap analysis can be completed; key indicators for performance assessment and a plan for the improvement of infrastructure management and service can be developed.

According to Naidoo (2007) the establishment and implementation of an automated and well-run complaints and faults system is an efficient way to monitor service quality, identify faulty infrastructure and monitor staff performance (DWAF, 2001; WSDP Section F8)

\section{PHASE 2 - WATER QUALITY MANAGEMENT}

\section{STEP 1: All necessary NWA Section 21 water use permits are in place and registered, and relevant by- laws exist or are under development}

Purpose: Enable the completion of WSDP Section 7, Section 3.2, Section 2.6, and Section 8.1.1.1.1; the monitoring of performance of WSA responsibilities; the measurement of compliance with NWA Section 21 water use permits; and the compilation of reports on these. The DWA staff will assist in accomplishing these tasks. The water use permits will vary according to the businesses and industries present in the regional municipal area. By-laws to regulate water service and wastewater discharge must be developed, promulgated and adopted.

\section{STEP 2: Establish an electronic chemical monitoring database to capture water quality data from the following units: incoming bulk water, potable water, water entering wastewater treatment plant, and discharge water}

- To monitor water quality and ensure compliance with water use specification and permits is critical to IWRM. Information generated in this task will enable the Water Service Provider to track the efficacy of the operational procedures; refine the chemical dosages for purification; and be alerted to malfunctioning wastewater treatment plants and accidental spills. This information is an essential prerequisite for risk assessment. All information generated must be forwarded to the central database of DWA Ww. DWA.gov.za//dir ws wsnis) in collaboration with an official who the Department will recommend. 
- Work towards establishing a regular microbiological monitoring system.

- Improve the household and bulk metering infrastructure to enable water balance and therefore a Water Conservation/ Demand Management plan.

\section{OUTCOME OF PHASE 2}

An efficient and dependable monitoring system for municipal functionality, and improved public credibility for municipal management with improved levels of payment for service.

\section{PHASE 3: OPERATIONAL, MAINTENANCE AND REHABILITATION STRATEGIES}

Sustainable management practices ensure the maintenance of a healthy environment by providing quality potable water, and cleaner rivers and wetlands (water resources); they ensure longer life for infrastructure and they enable the completion of WSDP Section 4, Section 7.1.1.3. These are all mandated responsibilities.

\section{STEP 1: Draft operational and procedural plans}

Purpose: Create reference documents to ensure operational sustainability despite staff changes.

Tasks: Of the essential municipal functions, the following are the most important to becoming IWRM compliant. Mandated functions of municipalities as water users include:

- Effective operation and maintenance of wastewater treatment works and ensuring compliance with licence conditions for discharge. Currently there are significant pollution problems arising from poor management of these facilities by municipalities (Schreiner, 2007).

- Effective operation and maintenance and refurbishment plans of infrastructure such as pipes, reservoirs, pumps and meters to minimise real water losses. This is now feasible due to the database established in Phase 1. During this task the maintenance history of each element will be established

- Control of alien invasive plants on the commonage and municipal dams. Municipal by-laws can be used for this purpose, or an assigned authority. Examples of how this can work have already been established.

- The formulation of by-laws and regulations to facilitate the management of water, waste and related functions (Schreiner, 2007).

Thus the tasks should be as follows:

- Publish procedures for purification, distribution, wastewater treatment, infrastructure inspections and maintenance plans, financial backlog eradication plans, and water conservation and demand management plans.

- Introduce a recorded complaints registration and response system.

- Assess the gaps and needs as the procedures are implemented and keep a record of implementation completion, thus allowing regular reviews.

- Introduce an environmental impact monitoring system, such as soil erosion, bank stability, the presence of exotic vegetation, to assess impact of operations on local environment.
The need for further by-laws and regulations will become evident during this process.

\section{STEP 2: Draft any outstanding by-laws and regulation according to available protocols to ensure adequate implementation of all water service delivery} functions

\section{OUTCOME OF PHASE 3}

Improvement in the management of wastewater treatment plants results in improved quality of water resources, and minimises water-borne diseases. Currently the water loss in municipal areas is unacceptably high (Schreiner, 2007). Management of this problem would assist considerably in managing water scarcity and improve the lifespan of infrastructure. The performance management system will also be refined. Once all management plans have been successfully implemented, capital projects such as major extension and refurbishment of overextended infrastructure can be properly budgeted.

\section{PHASE 4 - MONITORING AND REVIEW OF SERVICES}

Purpose: Undertake strategic gap assessments and lay the groundwork for development of implementation strategies to bridge these gaps.

Tasks:

- Annual review of service achievements and failures enabled by previous development of benchmarks.

- Introduction and maintenance of a performance appraisal system as demanded by law (Municipal Systems Act, No. 32 of 2000).

- Red-flagging consistent payment defaulters in various categories.

- Institute an environmental biomonitoring programme with assistance from citizens (CSIR, 2008).

These tasks form the basis of a sound service delivery strategy and should be reviewed annually to highlight gaps in service delivery. All municipalities should be managed according to agreed performance criteria. Risk assessment could be an outcome of the review process. DWA has developed several guidelines for environmental best practice monitoring and auditing, accessible from the DWA website (www.dwa.gov.za/IEM).

A feedback system will track all performances of the service departments; enable the adequate rewarding of compliant staff; report service excellence to the customer base, i.e. the citizens of the town; red-flag weaknesses in infrastructure; and create the ability to develop a rehabilitation strategy ranging from urgent to long-term.

\section{PHASE 5 - IMPLEMENTATION STRATEGIES FOR IWRM}

The links between mandated WSD and IWRM tasks are strong (Burke, 2007). Solid waste management and stormwater management are already mandated municipal management responsibilities. Practising IWRM as a service provider, therefore, requires some realignment of institutional structures and the adding of a few important new responsibilities to already existing directorates. If Phases 1 to 4 are implemented, the implementation of IWRM is achievable. 


\section{STEP 1: Create an integration forum}

Purpose: To create institutional support for altering the existing institutional framework so that there is greater integration and cooperation between the different sections.

Tasks:

- Appoint an integration champion at a sufficiently high level so that the realignment and coordination of relevant departments can proceed.

- Create a post for an Environmental Officer responsible for sustaining and overseeing the integration of all environmentally related functions.

\section{STEP 2: Realign operational areas}

Purpose: To move all functions that impact on water and environment into 1 entity where people have to meet and discuss management issues on a regular basis.

Tasks: Improve integration and cooperation between the operational areas of waste management, stormwater management and further the process of completing and updating the IDP.

\section{Waste management:}

- Link waste collection and transportation strategies to the consumer database.

- Record the location and description (including geology) of waste handling and storage site needs, with the potential impacts on both surface and groundwater resources identified.

- Classify waste and put in place class-appropriate treatment protocols for disposal and recycling, paying special attention to a hazardous waste register (including medical and veterinary waste).

- Link area cleaning of streets, lanes and parking lots to stormwater management.

- Drive community involvement and a communication system to prevent excessive littering that focuses on schools and ward-based environmental clubs

\section{Stormwater management:}

- Create management and maintenance plans that account for effects of urbanisation, waste management and an urban run-off strategy.

- Develop appropriate waste traps and wetland systems, especially near high-density areas.

- Pay attention to zoning areas for green lungs and soak-aways.

- Collaborate with land management experts to coordinate an environmental management plan.

\section{STEP 3: Maintain a healthy environment}

Purpose: To comply with the constitutional mandate of providing a healthy environment for citizens.

Tasks: Draft environmental management plans for catchment, river and wetland management and rehabilitation for water resource security (alien clearing of catchments) as well as parks and gardens, development of green lungs, soak-aways and maintenance of existing areas (paying attention to public health, including the inspection of public places).

\section{STEP 4: Review the IDP procedures and place water requirements at the heart of each sectoral plan outline}

Purpose: The development of the IDP is the ideal venue for pushing integration to the fore. However, the planning procedures do not as yet require that all plans include an evaluation of the water impacts of the plan. Risk assessment should, therefore, form part of the process.

\section{STEP 5: Complete the following new tasks required by the IWRM plan in order of importance}

\section{Monitoring systems and reports:}

- Develop a GIS-based data capture system to record and interrogate surface, groundwater and water users' information and monitoring points and draw maps of the area.

- Keep records of correspondence with other regulatory authorities.

- Initiate and/or improve auditing and reporting procedures (internal and external auditing).

- Develop bio-monitoring programmes in collaboration with DWA and DEA (Department of Environmental Affairs), the Catchment Management Agency and/or District Municipality.

- Make regular contact with DWA and DEA, the Catchment Management Agency, provincial and local government and the housing department and record these meetings.

\section{Management strategies:}

- Develop and promulgate all appropriate by-laws and regulations for each of the different categories of Section 21 water use with monitoring strategies for the Pollution Control Strategy (Section 8.12.5; 8, 10.9).

- Develop a community engagement and information strategy. Record partnerships with residents, NGOs and business.

- Improve the performance management strategy, to include key performance areas and key performance indicators for environmental and water resource management.

- Develop rehabilitation and mitigatory strategies, which outline management options to mitigate impacts and risks (Table 1).

- Develop an economic development strategy for creating employment and alleviating poverty.

- Develop a co-operative governance strategy which includes liaison with the CMA and other Water Services Authorities (Table 1).

- Project planning - review the project planning strategy and ensure that it follows the suggested outline from the IWRMP, with headings.

- Develop a methodology and selection criteria for new projects with timeframes for implementation procedures and management protocols.

- Risk assessment - identify potential emergency/contingency discharges referring to the Pollution Control Strategy. Identify possible impacts and risks to the environment and complete a quantitative and cumulative risk assessment (see Table 1, Section 8.9) with assistance from the District Municipality.

Additional information needed for the area description:

- Regional (CMA) perspective from the strategy of the WMA. 
- Hydrology: flow data, mean annual runoff obtainable from the WR90 series of information book supplied by the Department of Water Affairs and Forestry (now the Department of Water Affairs).

- Description of the catchment/s, Water Management Area and resource Class (from DWAF, 2004a).

- Overview of the geology of the area (geological maps).

\section{Skills and training needs}

The skills needed for the practising of IWRM may be somewhat different from those generally required in local government (Table 2). In addition, current municipal employees may require additional in-service training to master the new approach to management. The skills shortages in South African local government will not be overcome in the next 3 to 5 years despite increased efforts at training. Unless each municipality shows the foresight and determination of offering in-service training and training scholarships to able schoolleavers, this period will be even longer. In our opinion, the training of councillors must be made mandatory before they are inducted. A further suggestion that has been discussed is that the political parties should ensure that their candidates are offered training courses in the year prior to an election.

\section{Essential skills areas for district and local municipal management}

- Skill 1: Electronic data management. Ability to set up basic data capture systems in Windows Excel and to manage these data in an accessible form is a first-level skill essential for developing data management systems. Building, operating and maintaining a Geographical Information Systems (GIS) database system is an essential tool for effective municipal management. It is versatile and can be employed to store most inventories as well as produce maps. Data analyses and information production are toplevel skills needed for reporting to councillors in order to facilitate the making of informed decisions. A most useful combination of skills consists of a basic understanding of civil engineering, specialising in GIS. Councillors and municipal managers should understand the value of having a person with these important skills on the staff.

- Skill 2: Water resource management training, specifically knowledge based on an understanding of the natural environment (catchment processes - the geology, climatic conditions, topography of the area and groundwater) is a valuable asset in a municipal employee. If these characteristics are generally understood then disasters such as flooded neighbourhoods and emergency evacuations can be avoided. Understanding the geology and groundwater distribution of an area is important for the siting of solid waste disposal sites as well as the availability of emergency water resources. Although a basic degree in the natural sciences is useful, knowing where to find the information can be equally valuable. Basic graduate education also enhances an understanding of sustainable management practices. Postgraduate training in WRM would be the ideal.

- Skill 3: Training to improve water resource management includes tertiary level education in the physical sciences, importantly chemistry, biochemistry or microbiology. Water chemistry is important specialist knowledge since it is essential in the management of water quality, a core function of local government in both water service and water resource management. These skills are linked to the establishment of monitoring systems for water and air, as well as compiling a more general environmental monitoring plan. All of these skills link to data collection and analysis, as monitoring without being able to determine trends is a futile exercise.

- Skill 4: Familiarity with the legal framework for water resources and service management serves is a valuable aid to understanding roles, responsibilities and ensuring compliance, especially in the field of drafting by-laws and regulations.

- Skill 5: Management systems and implementation procedures such as financial management (understanding the importance of revenue collection as a factor in water service delivery is of cardinal importance).

Specialist skills that may have to be outsourced include hydrological modelling; groundwater and borehole flow analyses; risk assessment; sustainability analyses, monitoring systems and adaptive management.

\section{Conclusion}

The process set out in this guideline for finding simple, workable solutions to complex problems is intended to be a working document. Although the solutions proposed are simple they are not without difficulties. Finding and training staff with adequate skills will require dedication and resources. A team with vision, determination and sufficient support from politicians should be able to accomplish these 5 phases in 2 years. Phase 1 of the plan may take several years to accomplish, but several of the steps can be tackled simultaneously once the database structure has been established. The latter may be completed within a year while the customer and financial profiles are being developed.

Similarly Phase 2 can be tackled as soon as the correct staff have been engaged and the database structure has been settled. Establishing the NWA Section 21 authorisations required can be accomplished before any of the more time-consuming tasks such as recruitment are undertaken.

Phase 3 tasks, on the other hand, could not be completed successfully without either a database or the correctly trained engineering staff. We suggest the ground work could be laid by establishing a list of documents required and instituting a system for storing and tracking them. Drafting the strategies and developing the manuals may require the assistance of consultants. While Phase 3 may be complex, the establishment of monitoring systems required during Phase 4 should be put in place concurrently and is relatively straightforward.

Failure of data management and development of management plans/strategies are the bases of poor governance. The truism of 'you cannot manage what you don't understand' and 'knowledge is power' should be the maxims by which water service delivery implementers do business. Whether the approach to management is one of separation of operational areas or integration of similar operation areas, correct and accessible information is the key to success in our opinion.

IWRM demands a change in systems approach, and for water service delivery to incorporate such unallied tasks as solid waste management and housing development the integration of municipal functional units is the first requirement. In Phase 5 the appointment of an integration forum is advocated. For this group to be successful the benefits that these substantial changes in management bring must be clearly understood, well put forward and possible conflicts pre-empted by careful planning and exploring of all possible potential problem areas. 


\begin{tabular}{|c|c|c|c|}
\hline \multicolumn{4}{|c|}{$\begin{array}{c}\text { Table } 2 \\
\text { Summary of training needs of municipal sta }\end{array}$} \\
\hline Subject & Officials & Councillors & Purpose \\
\hline $\begin{array}{l}\text { Introduction to aquatic } \\
\text { ecosystem and environmental } \\
\text { functioning }\end{array}$ & $\begin{array}{l}\text { Interested and affected mem- } \\
\text { bers and engineering staff }\end{array}$ & $\begin{array}{l}\text { Yes, unless the person } \\
\text { already has a suitable } \\
\text { background (biology, sci- } \\
\text { ence /geography teacher) }\end{array}$ & $\begin{array}{l}\text { Gives sound understanding of functional } \\
\text { aspects of water as a resource and under- } \\
\text { standing of reasons for many laws and } \\
\text { regulations }\end{array}$ \\
\hline $\begin{array}{l}\text { Water Act: Chapter } 2,3 \& 4 . \\
\text { Interpretive, guided discus- } \\
\text { sion of relevant sections }\end{array}$ & $\begin{array}{l}\text { All officials in water service, } \\
\text { and municipal managers and } \\
\text { executive mayors to be tested }\end{array}$ & $\begin{array}{l}\text { Introduction needed for all } \\
\text { members }\end{array}$ & $\begin{array}{l}\text { Introduces South African philosophy of water } \\
\text { resource management and protection, licens- } \\
\text { ing and obligations of citizens }\end{array}$ \\
\hline $\begin{array}{l}\text { National Water Resource } \\
\text { Strategy - guided seminars on } \\
\text { relevant sections only }\end{array}$ & $\begin{array}{l}\text { All officials in water serv- } \\
\text { ices, municipal managers and } \\
\text { executive mayors }\end{array}$ & Interested parties only & $\begin{array}{l}\text { This is the implementation strategy of the } \\
\text { NWA and introduces approaches and strate- } \\
\text { gies in various sectors. It is also a valuable } \\
\text { information resource. An introduction to } \\
\text { WRM } 2005 \text { should be included }\end{array}$ \\
\hline $\begin{array}{l}\text { Water Services Act Chapter } \\
3 \& 4 \text {. Interpretive, guided } \\
\text { discussion of relevant sections }\end{array}$ & $\begin{array}{l}\text { All officials in water service, } \\
\text { municipal managers and exec- } \\
\text { utive mayors - to be tested } \\
\end{array}$ & $\begin{array}{l}\text { All councillors need this } \\
\text { for service on portfolio } \\
\text { committees }\end{array}$ & $\begin{array}{l}\text { This is the framework that outlines water } \\
\text { service responsibilities and guides all actions } \\
\text { and by-laws }\end{array}$ \\
\hline $\begin{array}{l}\text { Water Services Development } \\
\text { Plan - together with IWRMS }\end{array}$ & $\begin{array}{l}\text { Water service staff involved } \\
\text { in planning and the financial } \\
\text { manager }\end{array}$ & $\begin{array}{l}\text { Portfolio Committee } \\
\text { members }\end{array}$ & $\begin{array}{l}\text { Will ensure that correct people are appointed } \\
\text { in posts and that skills requirements are } \\
\text { understood }\end{array}$ \\
\hline $\begin{array}{l}\text { Integrated management } \\
\text { systems and adaptive manage- } \\
\text { ment principles }\end{array}$ & $\begin{array}{l}\text { Planning department, all } \\
\text { directors and deputy directors }\end{array}$ & $\begin{array}{l}\text { Portfolio Committee mem- } \\
\text { bers and interested parties }\end{array}$ & $\begin{array}{l}\text { Ensures the understanding of change needed } \\
\text { to undertake IWRM }\end{array}$ \\
\hline $\begin{array}{l}\text { Introduction to data manage- } \\
\text { ment and storage }\end{array}$ & $\begin{array}{l}\text { Finance, water, waste, and } \\
\text { human resources departments }\end{array}$ & Interested parties & $\begin{array}{l}\text { To ensure all members understand the value } \\
\text { of information generation and application }\end{array}$ \\
\hline Computer literacy & All plant operators & $\begin{array}{l}\text { All councillors with no } \\
\text { previous skills }\end{array}$ & Essential in the modern world \\
\hline $\begin{array}{l}\text { Data management systems, } \\
\text { spreadsheet and relational } \\
\text { data storage systems }\end{array}$ & $\begin{array}{l}\text { Selected employees in desig- } \\
\text { nated posts with basic skills }\end{array}$ & & Develops new skills \\
\hline Management systems & $\begin{array}{l}\text { Junior staff with no training in } \\
\text { management }\end{array}$ & Councillors & \\
\hline $\begin{array}{l}\text { Sewage plant operation } \\
\text { and wastewater quality } \\
\text { regulations }\end{array}$ & & All councillors & Understand roles and responsibilities \\
\hline $\begin{array}{l}\text { Potable water preparation, } \\
\text { water quality and drinking } \\
\text { water quality regulations }\end{array}$ & & All councillors & Understand roles and responsibilities \\
\hline
\end{tabular}

\section{Essential WSD \& IWRM source materials}

The listed documents should be in the council libraries and offices of all officials working in environmentally-linked directorates in local government:

- The Water Services Development Plan (Version 12) (www. DWA.gov.za//dir ws/WSDP/?curRes=1024)

- Self Appraisal Needs Analyses for Municipal Water and Sanitation Services Delivery. Also available from the above website.

- Burke J (2007) Integrated Water Resources Management Plan Guidelines for Local Authorities. WRC Report No TT304/07. Water Research Commission, Pretoria, South Africa (www.wrc.org.za).

- Guidelines for Catchment Management Strategies (2007) Department of Water Affairs and Forestry, Pretoria, South Africa. (www.DWA.gov.za//other/documents).

Websites that can provide useful resources for officials and councillors alike include:

- www.iclei-europe.org/

- www.doe.gov.za

- www.weather-sa.gov.za

- www.dplg.gov.za

\section{Acknowledgements}

This research was funded by the Water Research Commission, Pretoria, South Africa, under the programme framework for Local Government to Implement Integrated Water Resource Management Linked to Water Service Delivery (Project K5/16881). We wish to thank the Water Research Commission Steering Committee for guidance, especially J Burke. Thanks to D Anderson of Makana Municipality for cooperation.

\section{References}

BURKE J (2007) Integrated Water Resource Management Plan Guidelines for Local Authorities. Water Research Commission Report No. TT 304/07. Water Research Commission, Pretoria, South Africa.

CSIR (2008) The River Health Programme. URL: http://www.csir. co.za/rhp (Accessed 4 February 2008).

DEVELOPMENT FACILITATION ACT (1995) Development Facilitation Act (Act No. 67 of 1995), Republic of South Africa. URL: http://www.info.gov.za (Accessed 25 February 2007).

DISASTER MANAGEMENT ACT (2002) Disaster Management Act (Act No, 57 of 2002), Republic of South Africa. URL: http://www. dms-online.co.za/docs (Accessed June 2008).

DPLG (DEPARTMENT OF PROVINCIAL AND LOCAL GOVERNMENT, SOUTH AFRICA) (1998) White Paper on Local 
Government. Republic of South Africa. URL: http://www.info.gov. a (Accessed 23 November 2009).

DWAF (DEPARTMENT OF WATER AFFAIRS AND FORESTRY, SOUTH AFRICA) (2001) Water Services Development Plan (Version 12), Guidelines for Water Services Authorities. URL: http://www.DWA.gov.za//dir ws/WSDP (Accessed 23 November 2009).

DWAF (DEPARTMENT OF WATER AFFAIRS AND FORESTRY, SOUTH AFRICA) (2003) Strategic Framework for Water Services - DWA, DPLG, NT, SALGA. URL: http://www.DWA.gov.za// dir ws/WSDP/?curRes=1024 (Accessed 23 November 2009). DWAF (DEPARTMENT OF WATER AFFAIRS AND FORESTRY, SOUTH AFRICA) (2004a) The National Water Resource Strategy (including a strategy for Urban Water Conservation and Demand Management. URL: http://www.DWA.gov.za//dir wrm (Accessed 23 November 2009).

DWAF (DEPARTMENT OF WATER AFFAIRS AND FORESTRY, SOUTH AFRICA) (2004b) Guide framework and Checklist for the Development of a Water Services Management Plan. URL: http:// Www.DWA.gov.za//dir ws/WSDP/?curRes=1024 (Accessed 23 November 2009).

DWAF (DEPARTMENT OF WATER AFFAIRS AND FORESTRY, SOUTH AFRICA) (2004c) Water Conservation and Water Demand Management Strategy for the Water Services Sector. URL: http://www.DWA.gov.za/docs/Other/WaterUseConservation/ WCWDMWaterServicesAug04.pdf (Accessed 23 November 2009).

DWAF (DEPARTMENT OF WATER AFFAIRS AND FORESTRY, SOUTH AFRICA) (2005) Guidelines for Integrated Environmenta Management URL: http://www.dwa.gov.za/IEM (Accessed 19 April 2007).

DWAF (DEPARTMENT OF WATER AFFAIRS AND FORESTRY, SOUTH AFRICA) (2007a) The Catchment Management Strategy. URL: http://www.DWA.gov.za//documents/other/CMA CMSGuidelineFeb07 (Accessed 23 November 2009).

DWAF (DEPARTMENT OF WATER AFFAIRS AND FORESTRY, SOUTH AFRICA) (2007b) Self Appraisal Needs Analyses for Municipal Water and Sanitation Services Delivery. URL: http:/ www.DWA.gov.za//dir ws/Self\%20Appraisal $\% 20$ Needs $\% 20$ Analysis\%20for $\% 20$ Municip (Accessed 20 July 2008).

GEYER Y (2006) Integrated Development Planning - Handbook for CBOs. IDASA. URL: http://www.idasa.org.za/index.asp (Accessed 10 July 2008).

GLOBAL WATER PARTNERSHIP (2000) Integrated Water Resources Management. TAC Background Papers. URL: http:www.gwpforum.org./gwp/librarytacno\$pd (Accessed 23 June 2007). 4 pp,

HAIGH EH, FOX H, DAVIES-COLEMAN HD, HUGHES D, ATKINSON D and McCANN M (2008) The Role of Local Government in Integrated Water Resources Management Linked to Water Services Delivery. Water Research Commission Report No. 1688/1/08. Water Research Commission, Pretoria, South Africa.
INTERGOVERNMENTAL RELATIONS FRAMEWORK ACT (2005) Intergovernmental Relations Framework Act (Act No. 13 of 2005), Republic of South Africa. URL: http://www.info.gov.za (Accessed 26 May 2007).

LOCAL GOVERNMENT FINANCE MANAGEMENT ACT (2003) Local Government Finance Management Act (Act No. 56 of 2003), Republic of South Africa. URL: http://www.info.gov.za (Accessed 27 February 2007).

LOCAL GOVERNMENT PROPERTY RATES ACT (2007) Local Government Property Rates Act (Act No. 6 of 2004), Republic of South Africa. URL: http://www.info.gov.za (Accessed 27 February 2007).

MUNICIPAL DEMARCATION ACT (1998) Municipal Demarcation Act (Act No. 27 of 1998), Republic of South Africa. URL: http:/ Www.info.gov.za (Accessed 27 February 2007).

MUNICIPAL STRUCTURES ACT (1998) Municipal Structures Act (Act No. 117 of 1998), Republic of South Africa. URL: http://www. info.gov.za (Accessed 27 February 2007).

MUNICIPAL SYSTEMS ACT (2000) Municipal Systems Act (Act No 32 of 2000), Republic of South Africa. URL: http://www.info.gov. za (Accessed 27 February 2007).

MUNICIPAL SYSTEMS AMENDMENT ACT (2000) Municipal Systems Amendment Act (Act No. 33 of 2000), Republic of South Africa. URL: http://www.info.gov.za (Accessed 27 February 2007). NAIDOO S (2007) Personal communication, 11 July 2007. Consultant, Biwater (Pty) Ltd, P.O. Box 12753, Nelspruit 1200, Mpumalanga, South Africa.

NATIONAL ENVIRONMENTAL MANAGEMENT ACT National Environmental Management Act (Act No. 107 of 1998), Republic of South Africa. URL: http://www.info.gov.za (Accessed 16 February 2002).

NATIONAL TREASURY (2006) A Guide to Municipal Finance Management for Councillors. URL: http://www.treasury.gov.za (Accessed 17 May 2007).

NATIONAL WATER ACT (1998) National Water Act (Act No. 36 of 1998), Republic of South Africa. URL: http://www.info.gov.za (Accessed 25 January 2000).

SCHREINER B (2007) Personal communication, 16 August 2007. Deputy Director General, Policy and Regulation, Department of Water Affairs and Forestry, Pretoria, South Africa.

THE CONSTITUTION OF SOUTH AFRICA (1996) The Constitution of South Africa (Act No. 107 of 1996), Republic of South Africa. URL: http://www.gov.za (Accessed 25 January 2007).

UNDP (2003) Millennium Development Goals; a Contract among Nations to End Human Poverty United Nations Development Programme. URL

http://www.un.org/millenniumgoals/pdf/MDG Report 2003 ENG, pdf (Accessed January 2005).

WATER SERVICES ACT (1997) Water Services Act (Act No. 108 of 1997), Republic of South Africa. URL: http://www.gov.za (Accessed 27 February 2007) 